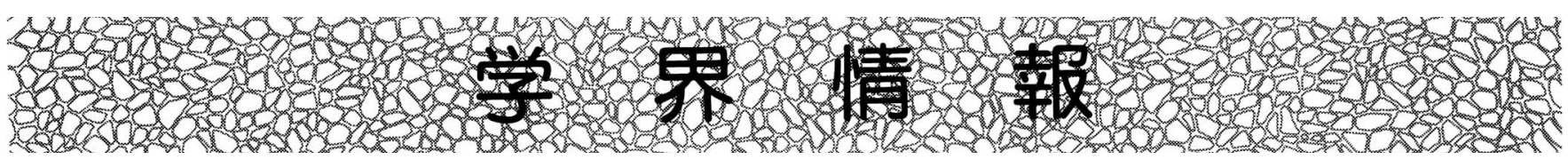

\title{
Asia-Pacific Power and Energy Engineering Conference (APPEEC 2010) 報告
}

\section{1. はじめに}

APPEEC (Asia-Pacific Power and Energy Engineering Conference）は 2009 年開始の国際会議であり, 第 2 回会議 APPEEC2010 が中国成都において 2010 年 3 月 28 日から 31 日まで開催された。成都は中国四川省の省都であり，辛 味やスパイスのきいた四川料理，ジャイアントパンダ，都 江堰（図 1）などで知られる。歴史的に成都は三国時代（三 国志の時代）における蜀の都でもあった。

中国武漢市で開催された APPEEC2009 と同様に, 本会議 は IEEE Power \& Energy Society (PES) の協賛で開催さ れた。他にも中国国家電網公司, Siemens 中国, 四川大学, 重慶大学, 武漢大学が協賛した。

\section{2. 会議の概要}

中国，日本，韓国，タイ，マレーシア，イラン，ロシア， 英国，オランダ，デンマーク，米国，オーストラリアから 800 人超の研究者や専門家の参加があった。筆者が見た限り では，大多数は中国からの参加であった。会議開始から 1 年と浅く，また開催場所が中国内陸部であったことにもよ るかと思われるが，中国国外の研究者にはあまり注目され ていないようである。しかしながら，一方では， APPEEC2010 が中国の電力業界における最新の成果を知 るとともに，電力技術に携わる中国の研究者との斬新な意 見交換を行うには好機であったことも事実である。

会議の 3 日間で，4 件の Plenary Speech，18 の口頭発表 セッション, 7 つのポスターセッションが開催された。セッ ション構成は，「系統計画・運用・最適化」や「系統制御」 のような従来の分野から,「スマートグリッド」,「風力・地 熱・波力エネルギー」，「エネルギー有効利用の新技術・設 計」といった新たな技術に関するホットな話題も含んで構 成されていた。会議において筆者の強い印象に残ったこと を 3 つ簡潔にまとめる。

・開会式では, IEEE PES の現在の部門長である Alan Rotz 氏が歓迎挨拶を行ったことには驚いた。氏は IEEE PES の管理運営についても紹介された。2008 年 1 月に北京に IEEE 中国オフィスを正式に発足して 以来, IEEE の各部門が中国における活動を立ち上げ 支援する取り組みが目立つようになってきている。

- 世界中の電力業界において熱い話題となっているスマ ートグリッドであるが，本会議においてもまさにその 話題に焦点を合わせていた。4 件の Plenary Speech す ベてにおいて，米国と中国の専門家らがそれぞれ独自 の視点，異なった捉え方でスマートグリッドに関する 議論が行われていた。さらに，「スマートグリッド」の

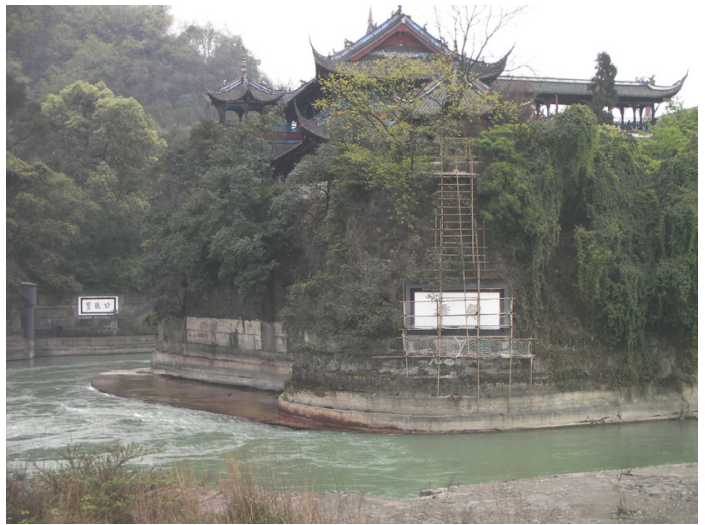

図 1 成都への水供給を一定に調整する宝瓶口（左奥） 手前の離堆には地震の爪痕が見られた

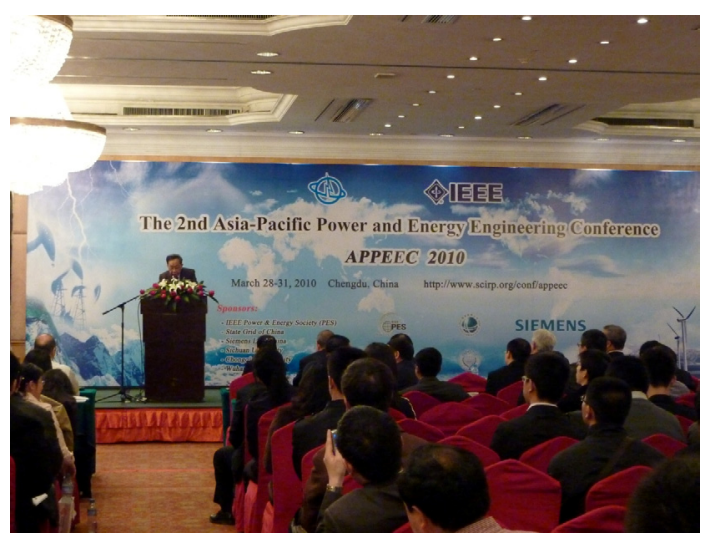

図 2 C. C. Chan 教授の講演

セッションは他のセッションに比べ, 多数の聴講者が あった。

- Plenary Speech では, 香港大学の C. C. Chan 教授が “Electric Vehicles and Smart Grid” の題目で講演さ れた（図 2)。実は，ここ 3 年間において筆者が Chan 教授の講演を拝聴するのは 3 度目であった。講演では, いつも情報と熱意に満ちており, 電気自動車技術の確 固たる支持者であることはもちろん，卓越した教育者 でもあるということを感じることができるであろう。

3. おわりに

次回，APPEEC2011 は再び中国武漢市において 2011 年 3 月 25 日から 28 日の日程で開催される。公式 Web サイト は www.scirp.org/conf/appeec2011 である。日本を含めた アジア太平洋地域からのより多くの参加者との出会いと意 見交換を楽しみにしている。

李 長松 [九州工業大学] (平成 22 年 4 月 19 日受付) 